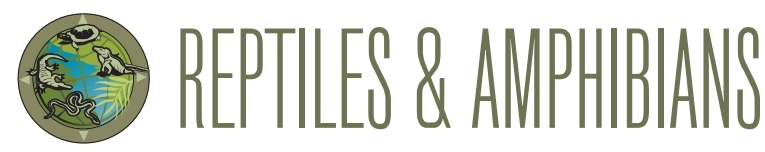

\title{
Larval Indian Bullfrogs (Hoplobatrachus tigerinus) Scavenging on an Indian Tiger Centipede (Scolopendra hardwickei)
}

\author{
Nariman Vazifdar ${ }^{1}$, Monowar Alam Khalid ${ }^{2}$, and Mervyn D'Costa ${ }^{3}$ \\ ${ }^{1}$ Mumbai, Maharashtra, India (narimanvazifdar@gmail.com) \\ ${ }^{2}$ Integral University, Lucknow, Uttar Pradesh, India \\ ${ }^{3}$ Ajmer, Rajasthan, India
}

A lthough larval anurans often are most conspicuous in standing water in temperate zones, tadpole assemblages can be very abundant and diverse in lotic habitats in the tropics (e.g., Inger et al. 1986; Whiles et al. 2006). Recent evidence suggests that generalized, rasping tadpoles incorporate a variety of animal matter into their diet, and cannibalism and scavenging are well documented for a variety of tadpole taxa (Crump 1983, 1992).

On 11 May 2021, NV observed larval Indian Bullfrogs (Hoplobatrachus tigerinus) scavenging a presumably drowned Indian Tiger Centipede (Scolopendra hardwickei) in a shallow cement trough where water had collected on Radhanagar Beach, Swaraj Dweep, Andaman and Nicobar Islands (Fig. 1). A recent heavy rainfall had triggered the emergence of many winged termites, a suddenly available and plentiful food source on which a variety of predators feast (Sekhar and Vidhyavathi 2018).

Three ways by means of which the centipede might have become accessible to the tadpoles are: (1) The centipede was trying to get at winged termites flying over the water trough and fell in; (2) the centipede was dislodged from the cement post by strong winds and landed in the water trough; or (3) the centipede was trying to eat the tadpoles and the undeveloped eggs but got stuck in the water trough and drowned. Centipedes foraging on a beach is not unusual; in fact, centipedes have been recorded hunting in pools in an intertidal zone and being caught by sea anemones (Moraes and Chagas-Júnior 2009).

During the initial observation, the larger, more developed tadpoles were actively scavenging especially the legs of
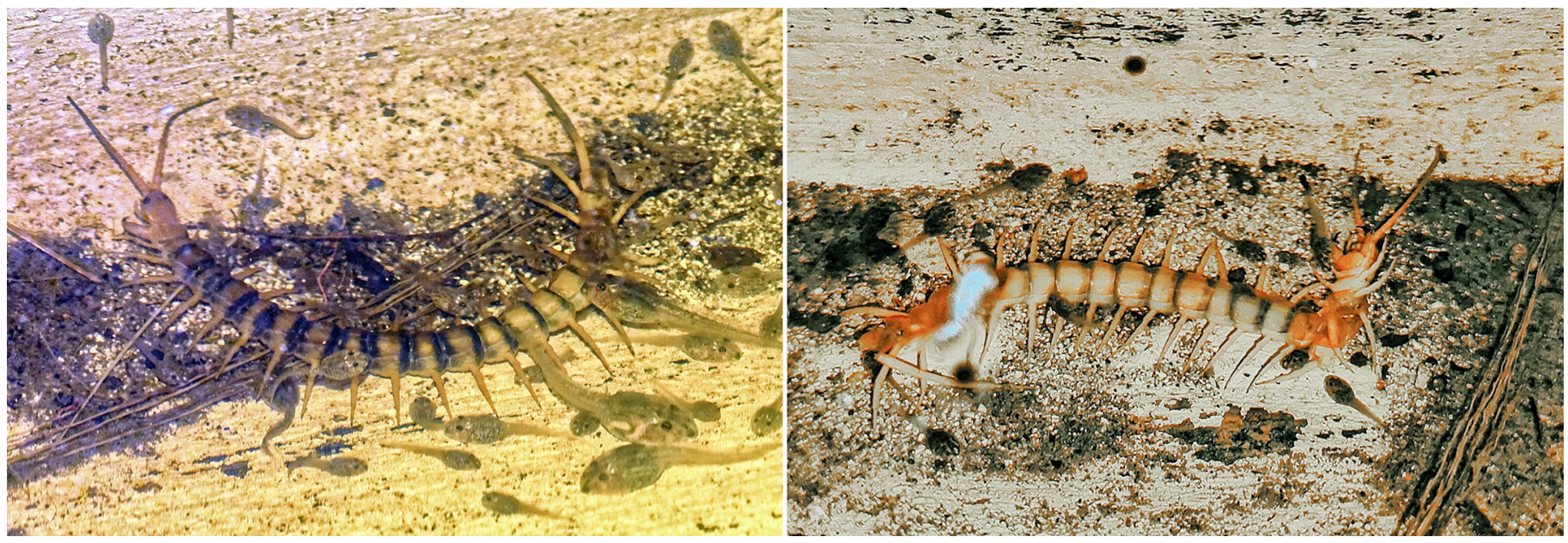

Fig. 1. Larval Indian Bullfrogs (Hoplobatrachus tigerinus) scavenging an Indian Tiger Centipede (Scolopendra hardwickei). Photographs by Nariman Vazifdar and Mervyn D’Costa. 

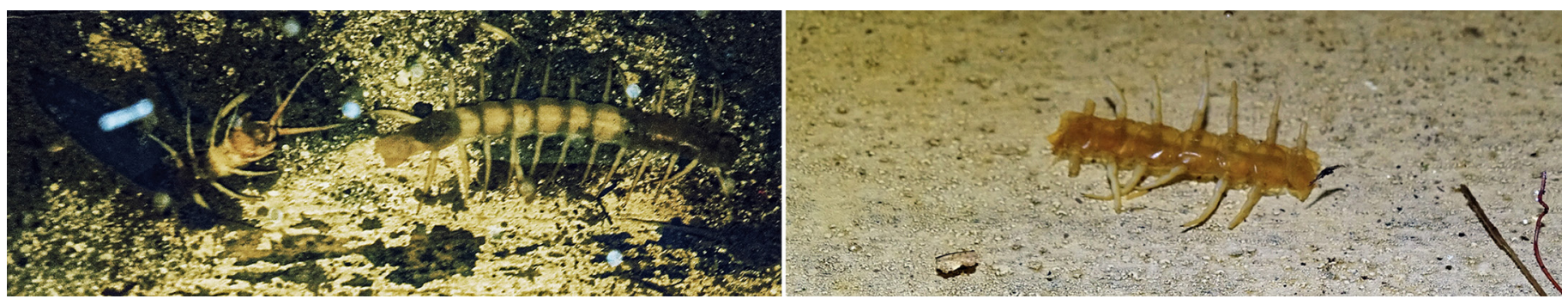

Fig. 2. Separated head and remaining segments of an Indian Tiger Centipede (Scolopendra hardwickei) after one day of scavenging by Indian Bullfrog (Hoplobatrachus tigerinus) tadpoles (left) and remnants of the exoskeleton after the second day (right). Photographs by Nariman Vazifdar and Mervyn D'Costa.

the centipede. By the next day, the head of the centipede had been detached and a few segments had been eaten, and by the second day, the entire centipede had been devoured and only the exoskeletal remains of a few segments were left (Fig. 2).

\section{Acknowledgements}

The authors thank various persons who have motivated us to write this note describing an interesting observation.

\section{Literature Cited}

Crump, M.L. 1983. Opportunistic cannibalism by amphibian larvae in temporary aquatic environments. American Naturalist 121: 281-287.

Crump, M.L. 1992. Cannibalism in amphibians, pp. 256-276. In: M.A. Elgar and
B.J. Crespi (eds.), Cannibalism. Ecology and Evolution among Diverse Taxa. Oxford University Press, Oxford, UK.

Inger R.F., H.K. Voris, and K.J. Frogner. 1986. Organization of a community of tadpoles in rain forest streams in Borneo. Journal of Tropical Ecology 2: 193-205. https://doi.org/10.1017.S0266467400000808.

Moraes, F. and A. Chagas-Júnior. 2009. Border between two worlds: the first record of sea anemone feeding on centipede. International Journal of Myriapodology 2: 215-217. https://doi.org/10.1163.187525409X12577705044700.

Sekhar, C. and A. Vidhyavathi. 2018. Termites and Food Security. AkiNik Publications, Rohini, Delhi, India.

Whiles M.R., K.R. Lips, C.M. Pringle, S.S. Kilman, R.J. Bixby, R. Brenes, S. Connelly, J.C. Colon-Gaud, M. Hunte-Brown, A.D. Huryn, C. Montgomery, and S. Peterson. 2006. The effects of amphibian population declines on the structure and function of Neotropical stream ecosystems. Frontiers in Ecology and the Environment 4: 27-34. https://doi. org/10.1890/1540-9295(2006)004[0027:twoapd]2.0.co;2. 